未来社会創造事業 探索加速型

「世界一の安全·安心社会の実現」領域

終了報告書(探索研究)

平成29年度採択研究開発代表者

\title{
[研究開発代表者名：河野 行雄］
}

[東京工業大学 科学技術創成研究院 未来産業技術研究所・准教授］

[研究開発課題名：マルチビュー画像計測技術によるエネルギー輸送インフラ の安全・安心運用の実現]

実施期間 : 平成 29 年 11 月 1 日〜令和 2 年 3 月 31 日 


\section{§1. 研究実施体制}

(1)「東京工業大学」グループ(研究機関名)

(1)研究開発代表者:河野 行雄（東京工業大学 科学技術創成研究院, 准教授)

(2) 研究項目

・電気・ガス検査用フレキシブルテラヘルツカメラならびに検査システムの開発

(2)「東北大学」グループ

(1) 主たる共同研究者:小山 裕（東北大学 大学院工学研究科, 教授）

(2)研究項目

•被覆電線内部の非破壊検査システムの構築

・トランス油漏れの遠隔検知システムの構築

\section{§2. 研究実施の概要}

電気やガスを事故なくユーザーへ届けることは，日常生活や産業現場の安心・安全を支える基盤となる。本 研究開発では, 2 つのエネルギー輸送インフラにおいて作業員の安全を確保しながら危険性をモニタリングする 技術を開発し, 誰もが安心して電気やガスを利用できる社会の実現に貢献することを目的とした。現在, 送電線 は目視による外観点検が主に行われているが,この点検では内部の損傷状況 (切断・腐蝕等) はわからない。そ こで本研究は, 電波としての透過性と光としての直進性を併せ持つテラヘルツ波を用いて, マルチビュー画像 計測による非接触・非侵襲な検査技術を開発することを目指した。この検查技術は，電気やガス等のエネルギ 一供給を止めることなく, 被覆の外から内部の損傷状況をリアルタイムで可視化することが可能となり, 社会にお けるエネルギーの安定供給に貢献するものである。

本計測システムにおいてキーとなる要素技術が，マルチビュー画像計測を可能にするフレキシブルテラヘル ツカメラと反射光学系である。基盤技術として，世界初のフレキシブル2次元マトリックス型テラヘルツカメラの開 発に成功した。さらに, 電線に照射すると内部素線の鏡面から反射・散乱するテラヘルツ波を検出する反射光 学系に, 多素子センサをアレイ化した撮像カメラを導入した。このシステムにより, 送電線や水素ガス配管のよう な 3 次元的に曲がった形状を持つ物体に対して, カメラを回転することなく撮像することができる。

被覆電線にテラヘルツ波を照射し, 被覆を透過して電線内部の素線表面からの反射もしくは散乱するテラへ ルツ波をカメラによって画像化するマルチビュー非破壊検査システムを設計・構築して, 被覆電線ならびに電線 の表面の計測に適用し，実際に非破壊で素線や破損，異物付着の画像化に成功した。また，同様のシステムを 油漏れ検知や水素ガス検知にも応用し，検出を確認した。多素子の信号を同時に読み込むことができるアルゴ リズムを適用し，検出デバイスの多素子化により撮像時間の大幅な短縮を図ることができた。これにより，現実的 な検査に適用可能なレベルにまで達した。

【具体的なユースケース(対象となるハザードの拡大も含む)及びそのインパクトの調査・検討】

プロジェクトメンバー全員でテラヘルツ波を用いる非破壊検査の現場適用をイメージしながら, 欠陥や故障部 分を明確にするシステム開発要素技術ならびに巡視対象の設備に関する視察と議論を行った。

電線・ガス以外でのテラヘルツ応用拡大も進めた。紙幣, 衣服などの䋊維や医薬品, 医療用器具, マウス臟 器(非侵襲医療診断用)などを対象として適用可能となることが分かった。 主要な成果:

1. D. Suzuki, Y. Ochiai, Y. Nakagawa, Y. Kuwahara, T. Saito, and Y. Kawano, "Fermi-levelcontrolled semiconducting-separated carbon nanotube films for flexible terahertz imagers", ACS 
Applied Nano Materials 1, 2469-2475 (2018). 研究代表者(河野)がTBSならびにテレビ東京の番組 に出演, 本研究成果の紹介

2. Xiangying Deng, Leyang Li, Mitsuhiro Enomoto, and Yukio Kawano, "Continuously Frequency" Tuneable Plasmonic Structures for Terahertz Bio-sensing and Spectroscopy”, Scientific Reports 9, 3498-1-9 (2019). Top 100 physics Scientific Reports papers in 2019 に選定

3. Daichi Suzuki and Yukio Kawano, "Flexible terahertz imaging systems with single-walled carbon nanotube films”, Carbon 162, 13-24 (2020). 